\title{
The Aleppo Boil and the Jewish Doctors: An Analysis of Leishmaniasis Research in Mandate Palestine
}

\section{Lauren Sillman}

\section{Introduction}

In 1924, Chaim Weizmann, who would eventually become the first president of Israel, asked Saul Adler, a parasitologist who had served in the British Army Medical Corps, to come to Jerusalem. The Hebrew University of Jerusalem was opening, and Dr. Adler was asked to help create an Institute of Microbiology. He remained with the university throughout his career, and, in coordination with the medical entomologist and Zionist Oskar Theodor, carried out extensive research on the vector-born, parasitic disease leishmaniasis throughout the 1920s and 1930s.

The early twentieth century was a time of flourishing scientific, and more specifically medical, research. "It is difficult now, in retrospect, to fathom the void when Adler and Theodor first entered this field,"1 a commentator in the 1980s reflected about their research on leishmaniasis. Adler headed the KalaAzar ${ }^{2}$ Commission of the Royal Society, "which greatly increased knowledge of this disease and the putative vectors at a time when this condition was also

${ }^{1}$ Yosef Schlein, “Obituary: Oskar Theodor,” Phytoparasitica 15 (1987): 345.

${ }^{2}$ Kala-azar is one name among many for cutaneous leishmaniasis. A few others are Aleppo boil, Baghdad boil, Oriental sore and Leishmaniasis tropica.

Colloquium for History Majors (World): Disease, Public Health and Empire, 16W:051. Instructor: Dr. Mariola Espinosa. Fall 2013, University of Iowa 
being intensively studied in Asia as well as Europe." 3 They were active participants in a vibrant international network of scientists, contributing to global medical knowledge through their publications in journals like the Annals of Tropical Medicine and the Bulletin of Entomological Research among many others.

They were active contributors to other types of international communities as well. The pair conducted much of their research in a Middle East that had just been apportioned by the British and the French after the fall of the Ottoman Empire in World War I. The British received control of Palestine, Iraq and Transjordan, while France added Syria and the soon to be created Lebanon to their colonial possessions. They were faculty at a Jewish university in Palestine at a time when political Zionism was becoming an increasingly significant force internationally and was gaining support from American Jews. They were also researchers in the field of tropical medicine, which, in its associations with colonial projects, ideologies of modernity, and systematic imbalances of power, was, and remains, difficult terrain to navigate as a scientist.

This paper will examine Adler and Theodor's position among the emerging Zionist scientific and medical institutions in Palestine during the interwar period. Jewish establishments became integral to the British system of governance, particularly in the provision of public health, and Britain's administrative decisions profoundly affected the status of Jewish and Arab populations in mandate Palestine as well as their future relations. An overview of the British Mandate system in Palestine insofar as it aggravated tensions between Arab and Jewish communities will help to explain the burgeoning of Zionist nationalism in the interwar period. Sandra Sufian has argued that, "Zionist public health measures were not only an important part of a comprehensive health project in Palestine, but that they were constituted by and constitutive of larger Zionist discourses and practices that promoted the establishment of the Jewish national home in Palestine." 4 This paper will examine her claim about public health policies and consider the extent to which another aspect of medicine — the conduct of research—functioned during this time of rigorous nation building.

${ }^{3}$ H. E. Shortt, "Saul Adler. 1895-1966," Biographical Memoirs of the Fellows of the Royal Society 13 (1967): 9.

${ }^{4}$ Sandra Sufian, Healing the Land and Nation: Malaria and the Zionist Project in Palestine, 1920-1947 (Chicago: University of Chicago Press, 2007), 19. 


\section{The Disease and the Research}

Leishmaniasis has multiple forms. The differences largely depend on the location of infection - cutaneous, visceral, and mucosal. ${ }^{5}$ Adler and Theodor did most of their work on the cutaneous form, which was and is the most prevalent in the region. Infection, by the bite of an infected sandfly, results in sometimes large and unattractive but usually painless sores. ${ }^{6}$ Generally an initial infection provides some degree of protection against recurring infection. Many of their experiments involved infecting themselves and volunteers in a variety of ways to determine the precise manner of transmission. ${ }^{7}$ They also experimented with different sandfly species and made considerable headway in discovering how the parasite travelled through the body of the insect vector. ${ }^{8}$

In 1929, they published a study called "The Distribution of Sandflies and Leishmaniasis in Palestine, Syria and Mesopotamia," which was a survey conducted over a tremendous area, including areas controlled by both the British and the French. They collected a large number of sandflies, dissected them in saline, and inspected them for traces of the leischmania parasite. They didn't intend for an exhaustive study, but they assumed the large area covered would allow for an analysis of the effects of topographical and climatic changes. Their explanation, "The distribution of Leishmaniasis in the countries under consideration is probably wider than the literature on the subject indicates, for with the increasing use of microscopial and cultural methods of diagnosis new foci are being discovered,"9 gives a sense of their scientific, technological context.

The methodology and the research itself are interesting, but the article also contains extensive references to people that were involved, in one way or

${ }^{5}$ These are terms that refer to the following loci in the body: skin (cutaneous), the nasal passages and portions of the pharynx connected to the mouth (mucosal), and internal organs, specifically the liver, spleen and bone marrow (visceral).

${ }^{6}$ Lord Melchett et al., Reports of the Experts Submitted to the Joint Palestine Survey Commission (Boston, Massachusetts: Daniels Printing Co., 1928), 619.

${ }^{7}$ Saul Adler and Osker Theodor, "Attempts to Transmit Leishmania Tropica by Bite: The Transmission of L. Tropica by Phlebotomus Sergenti," Annals of Tropical Medicine and Parasitology 23 (1929): 1.

${ }^{8}$ Saul Adler and Osker Theodor, "Additional Evidence on the Occurrence of L. Tropica in Wild Phlebotomus Papatasii," Annals of Tropical Medicine and Parasitology 23 (1929): 19.

${ }^{9}$ Saul Adler and Osker Theodor, "The Distribution of Sandflies and Leishmaniasis in Palestine, Syria and Mesopotamia" Annals of Tropical Medicine and Parasitology 23, (1929): 269. 
another, with their work. Adler cites other scientists extensively-people who were investigating leishmaniasis from Algeria and Tunisia to India and China. In the beginning, he acknowledges "Dr. Briercliffe of Jerusalem, Dr. Blowfield of Amman, Major Hallinan, Major Heggs, Dr. A. E. Mills, Dr. Hannah Khayat and Dr. Sammi Beg of Baghdad, Colonel Causeret and Dr. Mandour of Beyrout, Colonel Dagorn and Major Sondag of Aleppo." 10 Some of these figures play a larger role in the history books than others, but when taken all together, they represent a diverse network spanning states, professions, and colonial powers.

\section{The Creation of the Mandate and the Foundations for Conflict}

The immense area of their study traversed the boundaries of newly created states controlled by both the British and the French. These areas had largely been under Ottoman control for centuries. During the war, Britain made a series of contradictory agreements with Arabs, Jews and the French government, the legacies of which would impact the region for the remainder of the twentieth century. The Sykes-Picot Agreement, made in secret in 1916, defined the future British and French spheres of influence in the Middle East should the Triple Entente succeed in defeating the Ottomans. The boundaries determined in this agreement and revealed after the war were seen as incompatible with the wartime communications between Britain and Hussein bin Ali, a member of the ancient Hashemite family and sharif of Mecca, ${ }^{11}$ when he agreed to assist in the war against the Ottomans. Perhaps the most controversial British statement concerning the region during this period, however, was the Balfour Declaration of 1917.12 This document expressed

${ }^{10}$ Ibid.

${ }^{11}$ The Hashemite clan was an Arabian dynastic family. Hussein bin Ali had maintained poor relations with the Young Turks who controlled Istanbul before the outbreak of World War I. He made an alliance with the British that he believed would result in the acquisition of a great deal of territory after the war. When his aspirations failed to materialize, his son Faisal attempted to assume leadership in Syria, but he was quickly defeated by the French. Faisal ultimately assumed the throne in Iraq, while his brother Abdullah became king in the new kingdom of Transjordan.

12 "His Majesty's Government view with favor the establishment in Palestine of a National Home for the Jewish people, and will use their best endeavors to facilitate the achievement of this object, it being clearly understood that nothing shall be done which may prejudice the civil and religious rights of existing non-Jewish communities in Palestine, or the rights and political status enjoyed by Jews in any 
support for Zionist objectives but remained vague about the type of Jewish presence Britain would encourage in Palestine.

After the war, the Middle East was divided up mostly according to the Sykes-Picot Agreement. The mandates were formally established at the San Remo Conference in 1920 and recognized by the League of Nations. These mandates had a slightly different legal status from Britain's other colonial possessions. Informed by Wilsonian ideals of self-determination, the League of Nations was only willing to sign off on British and French authority that was, at least nominally, aimed at future independence after some undetermined period. This new form of colonialism, which was already inherently more fragile than other colonial situations, was further undermined by the contradictions in British communications during the war and the fraught relationship between the Arab and Jewish communities.

Adler and Theodor published their distribution survey in 1929, which was the same year as the first of two periods of communal violence in the interwar period, the Wailing Wall Disturbances of 1929. The second period of major violence began in 1936 and lasted until 1939. A report to the League of Nations summarizes the circumstances in 1930, "The Commission on the 1929 disturbances recommended that His Majesty's Government should consider the advisability of issuing with the least possible delay a clear statement of the policy which they intend to pursue in Palestine."13

A statement did come in the form of the Passfield White Paper of 1930, despite the fact that, "at the beginning of 1930 owing to the animosity engendered by the disturbances of 1929, Jewish and Arab claimants were unwilling to meet in the villages for the preliminary investigation of claims, and the work of the Settlement Officers was retarded." 14 The document dealt with some of the Arab grievances and placed restrictions on Jewish immigration. Within a year, however, Jewish politicians, including Chaim Weizmann convinced the British government to rescind the policies outlined in the document, indicative of the disproportionate influence the Jewish community had with the British government but also characteristic of Britain's

other country." Cited in William Cleveland and Martin Bunton, A History of the Modern Middle East, $5^{\text {th }}$ ed. (Boulder, Colorado: Westview Press, 2013).

${ }^{13}$ Government of the United Kingdom, Report to the Council of the League of Nations on the Administration of Palestine and Trans-Jordan for the Year 1930, Boston: United Nations Information System on the Question of Palestine.

${ }^{14}$ Cleveland and Bunton, A History of the Modern Middle East, 238. 
unwillingness to actively pursue definitive solutions during whole course of the interwar period.

\section{Zionism, Nationalism, and the Project of Health}

Colonization and the creation of a national home in Palestine were fully articulated and widely espoused objectives of Zionism by this point in history. ${ }^{15}$ The Colonization Department of the Zionist Organization was active and well funded. ${ }^{16}$ The Palestinian Office of the World Zionist Organization, founded by Theodor Herzl and the First Zionist Council in 1897, became the Jewish Agency in 1929. The Agency remains the largest Jewish non-profit organization responsible for immigration of Diaspora Jews into Israel. The comments of David Amram, who was the chairman of the Philadelphia Zionist Council, on democracy in Palestine reveal the attitude underlying much of the Zionist activity at the time:

The Zionist did not expect that "Palestine should be handed over to them together with its Christian and Mohammedan populations who should nilly willy be governed by a handful of immigrant Jews" ... [but] that the Zionists simply asked for the right to bring in immigrants, "under international protection," until they are numerically strong enough "to rule the country." 17

Beyond a numerical majority, Zionists also sought to consolidate power in the region through developmental activities. From her research on malariaprevention schemes in Palestine at this time, Sandra Sufian has found that, "Zionist medical discourse promoted the nation-building processes of settlement, labor, and land purchase as well as the creation and consolidation of national scientific institutions." 18 Notions about modernity were powerful constitutive elements of Zionist nationalism. The Jewish people possessed a shared history of exclusion and alienation, but this was a history that could be transformed through progress and development. Jews now had the

15 This was not the case earlier in the history of political Zionism. Many preceding Zionists aimed for political agency within their existing governments. Others advocated for settlement in places besides Palestine. A popular early choice was Uganda.

${ }^{16}$ Joint Palestine Survey Commission, Reports of the Experts Submitted to the Joint Palestine Survey Commission (Boston, Massachusetts: Press of Daniels Printing Co., 1928), 592.

${ }^{17}$ Cited in Raphael Medoff, Zionism and the Arabs: An American Jewish Dilemma, 18981948, (Westport, Connecticut: Praeger Publishers, 1997), 24.

${ }^{18}$ Sufian, Healing the Land and Nation, 6. 
opportunity to fashion a nation that was both legitimated by a shared past and directed towards a promising future.

The body, in all its physicality, was an important site for the manifestation of this convergence, between historicity and progress, at the heart of Zionist nationalism. Zionist propaganda was preoccupied with the human figure. One of the most significant organizations in Mandate Palestine was the Histadrut, the Federation of Jewish Labor. ${ }^{19}$ Zionist nationalists needed to assert selfsufficiency, and the physical work of laborers served as a symbol of this capacity. A Hungarian advertisement for settlement in Palestine featured hearty, attractive laborers, tanned from the sun amid a verdant field. ${ }^{20}$ This stands in contrast to the stereotypical image of a pale, thin ghetto-dweller. One perceived feature of Arabs, among few, that Zionists were complementary of was their strength and virility. Zionists hoped that this strength and virility would come to define the Jewish nation.

Pestilence and disease threatened to mar the image of the new, strong Jew, however. Certainly the disfiguring effects of Leishmaniasis would not benefit the nationalist aesthetic. Widespread famine and disease throughout the Middle East, exacerbated by the devastations of the war, left a region that the statisticians described in terms of high rates of infection and infant mortality. In an American Zionist magazine originally published in Yiddish in 1897, Palestine is described as a desolate place "where the worms eat the living as well as the dead," 21 and this characterization persisted in varying degrees up until Adler and Theodor's time. The means of reconciling perceptions of Palestine as barren, primitive and diseased with the hopes for a Jewish homeland was the cultivation of a nationalism based on ideas of development, progress and public health.

In 1928, Milton J. Rosenau, who would play an important role in the creation of the School of Public Health at Harvard, and Charles F. Wilinsky, later president of the American Public Health Association, carried out a survey of public health as part of the Joint Palestine Survey. Not only is the survey a valuable source of information about interwar Palestine, it is also a glimpse of American perceptions at the time. The authors partake in the quasi-spiritual, symbolic function of health:

${ }^{19}$ Cleveland and Bunton, A History of the Modern Middle East, 232.

${ }^{20}$ Andrew Hamilton. "The End of Zionism." Spre O Viata Noua.

${ }^{21}$ Cited in Medoff, Zionism and the Arabs, 35. 
We were inspired with the opportunity to visit and serve the Canaan of our fathers, the Palestine of today ... It was with a sense of deep humility that we stood in the holy places of the Holy Land and thought of the great traditions which have become our heritage, but especially the teachings of Moses who was the first great sanitarian. ${ }^{22}$

They never explain elsewhere what exactly they mean by calling Moses the "first great sanitarian," but it is clear that, as Moses was the literal harbinger of the rules of good conduct and virtue, spiritual and physical well-being are conflated.

These different aspects of health are connected further when the authors explain, "We are inclined to place cleanliness even before godliness, for cleanliness of body, cleanliness of mind and soul, and cleanliness of surroundings are essential to a full appreciation of the spiritual virtues." ${ }^{23}$ The excessive spiritualization of cleanliness and hygiene in this example may have been an extreme case, but health was, at the very least, elevated as an ideal. Sufian argues that "Zionist health propaganda produced a nationalized version of scientific knowledge for the Jewish public . . Individual subordination to national priorities was a common element in public health planning of the period." 24 Public health served to mobilize people, superseding their individuality to direct the body politic towards a common goal, and who can argue against the value of public wellbeing? However, the fact that benefits of the health system were directed preferentially towards a specific group of the population complicates the notion of "public" health.

\section{Support from Abroad}

In one of their studies, Adler and Theodor cite someone named Dr. E. Libman, "whose generosity enabled us to carry out this work." 25 There is no further description in the article, but this Dr. Libman was most likely Emanuel Libman, a prominent Jewish doctor from New York. He played a fairly substantial role in American Jewish politics at the time and was a significant contributor to Jewish philanthropic organizations. In his obituary, Bernard Oppenheimer said that, "he was a great friend of, and liberal contributor to the

\footnotetext{
22 Joint Palestine Survey Commission, Reports of the Experts, 741.

23 Ibid., 567.

${ }^{24}$ Sufian, Healing the Land and Nation, 252.

25 Adler and Theodor, "The Distribution of Sandflies," 301.
} 
Hebrew University in Palestine." 26 Emanuel Libman was only one among many.

Much of the strength of the Zionist mission arose from the extensive Jewish international financial, political, scientific and social networks. Colonel Heron, the British Minister of Health during the mandate period, noted that Dr. Kligler, who was instrumental in the foundation of the Hebrew University and a close associate of Adler and Theodor, "began his anti-malarial work in Palestine with the Hadassah Medical Organization in the spring of 1921 under a grant of $\$ 10,000$ made by Mr. Justice Brandeis." 27 In 1918, Hadassah, which was originally an American Jewish Women's Organization, established the American Zionist Medical Unit, manned by 45 medical health professionals. The American Zionist Medical Unit helped to establish six hospitals in Palestine that were eventually turned over to municipal authorities.

This last example helps to illustrate another important point. The British did not have a strong interest in creating an optimal public health system. The terms of the British government's mandate limited the investments it was willing to make in a region it would eventually leave. Therefore, the administrators in Palestine frequently claimed Zionist institutions as part of their Ministry of Health. Sufian, in her work on malaria, discusses how the Malaria Research Unit was administered by the Joint Distribution Committee, which to this day is the largest Jewish humanitarian assistance organization, but was situated within the British Mandate's Ministry of Health.

She identifies the problem in the set-up, in that, "The resulting situationan autonomous, well-organized, and relatively well-financed system run by the Zionists, and an Arab population dependent upon a limited British health system and missionary efforts - maintained and perhaps deepened the social gap between the two communities." 28 Even the Joint Palestine Survey Commission openly emphasized the Jews, saying, "While this report is based upon a study of the hygienic and sanitary conditions of Palestine in general, our interest focused itself upon the health and well-being of the Jewish people, for

${ }^{26}$ Bernard S. Oppenheimer, "Emanuel Libman, 1872-1946," Bulletin of the New York Academy of Medicine 23 (1947): 116-117.

${ }^{27}$ Colonel Heron, "Prefatory Note, 1922," 1921-1932 New York Collection, American Joint Distribution Committee Archives, Accessed November 10, 2013, http://archives.jdc.org/.

${ }^{28}$ Sufian, Healing the Land and Nation, 12. 
whom health work is done by a variety of agencies." ${ }^{29}$ As an external reporting commission, it is problematic that they focused their attention on a community that was still, by a large measure, in the minority.

Beyond their American Jewish financier, Adler and Theodor also focused their distribution survey on a disproportionate number of Jewish settlements. Aside from the large metropolitan areas, the smaller towns that the pair collected samples from were largely Jewish. One of these was Rosh Pinna, a fairly minor town in terms of population but significant in that it was founded by Romanian Jewish immigrants as one of the first Zionist settlements in the nineteenth century.

\section{Apportioning Blame and Claiming Modernity}

The unequal balance of resources for health predictably tended to manifest itself in the unequal burden of disease. Rarely, however, was poor health attributed to socio-economic factors. "There is the prejudice of centuries to consider," 30 the author of the Joint Palestine Survey explains to his audience. In Adler and Theodor's distribution survey, they frequently link the poor quality of a family's housing, which facilitated and increased the rates of sandfly breeding, to their Arabness rather than any other demographic descriptor. In almost the exact same manner, the Joint Palestine Survey says:

Some of the better and newer houses in Palestine are as nice, clean and satisfactory as similar dwellings in the United States or in England. Such, however, are rather the exception, because for the most part the housing conditions are primitive, elemental and unsanitary. Most of the houses are crowded, with poor ventilation, especially those of the Arabs in cities and villages. ${ }^{31}$

The words, "primitive, elemental, and unsanitary," reappear frequently in almost all of the literature about Palestinians, and particularly Palestinian Arabs, from this period. The authors of the Joint Palestine survey explain this backwardness and unsophistication, saying, "Furthermore, in many parts of our fair country, especially in the rural sections, will be found similar primitive and unsatisfactory conditions that now exist in parts of Palestine." 32 Their

\footnotetext{
${ }^{29}$ Joint Palestine Survey Commission, Reports of the Experts, 560.

${ }^{30}$ Ibid., 560.

31 Ibid., 569.

32 Ibid., 561.
} 
American example advances an implicit claim. The unsatisfactory conditions in Palestine can be remedied, but to do so requires that the Arabs' primitivism be overcome.

Ignorance was not the only problem in their opinion, however. In an analysis of the various health statistics they collected, the author explains, "We have been taught to regard infant mortality as a fair index of a community's application of modern public health principles, and the appalling loss of young children in Palestine suggests avoidable negligence." 33 The principles of modernity are present, and the fact that Palestinians continued to have poor markers of health in the face of the ideals of public health was, to the commissioners, indicative of negligence. These same perceptions arise again in an analysis of trachoma in children, "All this is readily preventable and is due to a combination of ignorance, indifference, neglect, accentuated by the irritating glare of the sunshine, the prevalence of dust, the menace of flies, the danger of contagion, and the effects of heat." 34 When these perceptions were combined with the conflation of hygiene and virtue and skewed the distribution of health resources, the implications for intercommunal relations in Palestine became highly problematic.

As the authors give suggestions for modifications in the public health system, they explain that many other countries have suffered from poor health in the past, but then "they saw the light; sanitation was improved, communicable disease was controlled, infant welfare in a measure safeguarded, other health measures promoted, and infant mortality rate consequentially reduced." 35 They placed responsibility entirely in the hands of "the ignorant," who must be "shown the light" in order to improve their own welfare. "The light" is the knowledge produced by the scientists and doctors. By establishing and supporting a community of scientists, the Zionist movement promoted intellectual self-sufficiency in addition to the self-sufficiency of labor and goods. The cultural capital that comes with innovation was of vital importance to the Zionist movement and the creation of a viable, competitive nationalism. Sufian reflects, "In the eyes of the Jewish scientists, such recognition would indirectly show that the fledgling Zionist national movement could enjoy credibility among the civilized world; they could prove to themselves and to others that they were capable of ruling themselves and establishing a Jewish

\footnotetext{
33 Ibid., 576.

34 Ibid., 593.

${ }^{35}$ Ibid., 577.
} 
National Home." 36 Many of these Zionists were originally from Europe and thus came to Palestine with an awareness of, and respect for, European institutions and models of learning and innovation. Zionists did not want the homeland in Palestine to be isolated from these networks, but rather to put forth competitive contributing members.

Saul Adler received considerable recognition during his life both from the international scientific community and from his community at home in Jerusalem. His biographer tells an anecdote, meant to illustrate his absentmindedness, about when Dr. Adler got lost as he was walking around the city. His biographer explains, "Almost anyone in Jerusalem would know him, so he stopped by a passer-by and asked him where Professor Adler lived." ${ }^{37}$ This story illustrates something more striking than his memory lapse, however. It is almost extraordinary that any random passerby would recognize Saul Adler, a parasitologist and entomologist studying a non-lethal disease at a university. His fame was enough to earn him a place on one of the early Israeli stamps. His face, and the associated spirit of science and research, became a symbol for a new nation, one among many formative factors of a developing, post-Mandate Palestine, Israeli character.

\section{Conclusion}

Scientific, and more specifically medical, research has never existed in a vacuum. Scientists have never been able to escape the influences of their communities, nations or cultures to act as an independent, objective, and disinterested observers. This was especially true for Adler and Theodor who conducted research as near celebrities in very complex domestic and international circumstances. In general, the compromised positions of researchers were especially evident in communities of scientists who worked in colonial settings. When systems based on the unequal distribution of power were already in place, doctors who came in to perform research on colonial "subjects" were at risk of amplifying existing inequalities. Adler and Theodor faced the additional pressures of an emerging Jewish nationalism that made claims about the region they were working in and the developmental possibilities inherent in their research.

36 Sandy Sufian, "Colonial Malariology, Medical Borders, and Sharing Scientific Knowledge in Mandatory Palestine," Science in Context 19 (2006): 386.

${ }^{37}$ Shortt, "Saul Adler," 4. 
Unfortunately, with the end of formal colonization, the concerns this paper highlighted have not become irrelevant. The legacies of colonization persist, compounded by disastrous wars, policies, and opportunistic political and private interventions. Systemic inequality persists, and the proliferation of new technologies and novel methods of research could succumb to similar instrumentalization by discrete groups to produce divisiveness and inequality. On the other hand, by recognizing the shortcomings in this case and others, opportunities to better protect the rights and dignity of individuals, regardless of ethnicity, religion, nation, or other factors, become more apparent.

\section{Sources Consulted}

Adler, Saul, and Oskar Theodor. "Attempts to Transmit Leishmania Tropica by Bite: The Transmission of L. Tropica by Phlebotemus Sergenti." Annals of Tropical Medicine and Parasitology 23. Liverpool: University Press of Liverpool (1929): 1-16.

Adler, Saul, and Oskar Theodor. "Additional Evidence on the Occurrence of L. Tropica in Wild Phlebotomus Papatasii." Annals of Tropical Medicine and Parasitology 23. Liverpool: University Press of Liverpool (1929): 19-21.

Adler, Saul, and Oskar Theodor. "The Distribution of Sandflies and Leishmaniasis in Palestine, Syria and Mesopotamia." Annals of Tropical Medicine and Parasitology 23. Liverpool: University Press of Liverpool (1929): 269-307.

Choueiri, Youssef M. ed. State and Society in Syria and Lebanon. Exeter: University of Exeter Press, 1993.

Cioeta, Donald J. “Ottoman Censorship in Lebanon and Syria, 1876-1908.” International Journal of Middle East Studies 10 no. 2 (May 19799): 167-187.

Council of the League of Nations. "French Mandate for Syria and the Lebanon." The American Journal of International Law 17, No. 3, Supplement: Official Documents (July, 1923), 177-182.

Cleveland, William L., and Martin Bunton. A History of the Modern Middle East. Boulder, CO: Westview Press, 2013.

Gafaiti, Hafid, Patricia M. E. Lorcin, and David G. Troyansky, eds. Transnational Spaces and Identities in the Francophone World. Lincoln, NE: University of Nebraska Press, 2009.

Gelvin, James L. Divided Loyalties: Nationalism and Mass Politics in Syria at the Close of Empire. Berkeley, CA: University of California Press, 1998.

Government of the United Kingdom. 1930. Report to the Council of the League of Nations on the Administration of Palestine and Trans-Jordan for the Year 1930. Boston: United Nations Information System on the Question of Palestine. 
Grossi, Ken, Maren Milligan, and Ted Waddelow. "King Crane Commision Digital Collection." Oberlin College Archives. Last modified 2011. Accessed October 26, 2013. http://www.oberlin.edu/library/digital/king-crane/.

Hourani, Albert. Arabic Thought in the Liberal Age 1798-1939. Cambridge: Cambridge University Press, 1983.

Hovnanian, Philipp, and H. A. Yenikomshian. "Dermal Leischmaniasis in a Newly Inhabited Section of Aleppo.” Royal Society of Tropical Medicine and Hygiene 31 (19371938): 191-198.

Joint Palestine Survey Commission. Reports of the Experts Submitted to the Joint Palestine Survey Commission. Boston, Massachusetts: Press of Daniels Printing Co., 1928.

Khalidi, Rashid Ismail. British Policy Towards Syria and Palestine 1906-1914: A Study of the Antecedents of the Hussein — the McMahon Correspondence, the Sykes-Picot Agreement, and the Balfour Declaration. London: Ithaca Press, 1980.

Khoury, Philip S. Syria and the French Mandate: The Politics of Arab Nationalism, 1920-1945. Princeton, NJ: Princeton University Press, 1987.

Lord Melchett, Lee K. Frankel, Felix M. Warburg and Oscar Wasserman. Reports of the Experts Submitted to the Joint Palestine Survey Commission. Boston, Massachusetts: Daniels Printing Co., 1928.

Schlein, Yosef. “Obituary: Oskar Theodor.” Phytoparasitica 15 (1987), no. 4.

Shortt, H.E. "Saul Adler. 1895-1966." Biographical Memoirs of the Fellows of the Royal Society 13 (November 1967).

Sufian, Sandy. 2006. "Colonial Malariology, Medical Borders, and Sharing Scientific Knowledge in Mandatory Palestine." Science in Context 19, no. 3.

Sufian, Sandra M. Healing the Land and Nation: Malaria and the Zionist Project in Palestine,1920-1947. Chicago: University of Chicago Press, 2007.

U. S. Department of Health, Education and Welfare. 1977. Syncrisis, The Dynamics of Health: An Analytic Series on the Interactions of Health and Socioeconomic Development, XXIII The Syrian Arab Republic.

Watenpaugh, Keith D. Being Modern in the Middle East: Revolution, Nationalism, Colonialism, and the Arab Middle Class. Princeton, NJ: Princeton University Press, 2006. 